https://doi.org/10.18485/bogoljub_stankovic.2018.ch2

811.163.1'373

\author{
МАРИЯ МИХАЙЛОВНА ВЕРЕИТИНОВА* \\ Белградский университет \\ Филологический факультет \\ Московский государственный университет \\ им. М.В.Ломоносова
}

\title{
МЕТОДИЧЕСКАЯ МОДЕЛЬ ПРЕДСТАВЛЕНИЯ АКТУАЛИЗИРОВАННОЙ ПАРОНИМИЧЕСКОЙ ЛЕКСИКИ В СЕРБСКОЙ АУДИТОРИИ
}

В статье рассматривается поэтапная организация процесса обучения актуализированной паронимической лексике (подготовительный (предтекстовый), притекстовый и послетекстовый этапы) в серббской аудитории. Приводятся примеры из данного комплекса упражнений и заданий.

Ключевые слова: актуализованные паронимы-прилагательные, паронимические парооппозиции, паронимические ряды, общедидактические принципы, лингводидактические принципы, комплекс упражнений

Maria Mikhailovna Vereitinova

\section{METHODICAL MODEL OF THE REPRESENTATION OF ACTUALIZED PARONYMIC VOCABULARY FOR SERBIAN STUDENTS}

The article considers the gradual organization of learning paronymous words at Russian lessons for Serbian students.

Keywords: actualized paronymous adjectives, paronymous oppositions, paronymous sets/fields, general didactic principles, linguo-didactic principles, exercises

Активные лексико-семантические процессы в современном русском языке последнего десятилетия, вызванные общественными трансформациями новейшего времени, требуют изучения как в аспекте теоретической, так и прикладной лингвистики.

Без овладения словарным запасом невозможно ни понимание речи других людей, ни выражение собственных мыслей. По этой причине ра-

*rkiff@philol.msu.ru 
боте над лексической стороной речи на всех этапах обучения русскому языку отводится исключительное большое место (Щукин 2003: 59).

Актуализированная паронимическая лексика широко представлена в современных российских СМИ, поэтому очень важной представляется дифференциация актуализированных паронимических лексем при обучении серббких учащихся русскому языку как иностранному.

Система обучения актуализированным паронимам прилагательным основывается на совокупности основополагающих принципов (общедидактических и лингводидактических), среди которых В.Г. Костомаров и О.Д. Митрофанова выделяют принцип сознательности, согласно которому усвоение актуализированной паронимической лексики предполагает осознание учащимися значений паронимов и их связей с другими словами (Костомаров, Митрофанова 1984: 22).

Приниип связи теории с практикой, по мнению исследователей, предполагает умение учащихся применять полученные знания, навыки и умения в своей практической деятельности. Связь теории с практикой осуществляется при обучении актуализированной паронимической лексике, т.к. среди паронимов есть и термины, которые позволяют расширить знания по специальности сербских учащихся.

Приниип системности при обучении паронимической лексике проявляется в учёте этапности в формировании лексических навыков, в последовательности расположения упражнений, а также в расположении текстового материала в соответствии с логикой, определяемой структурой предмета.

Прини,и преемственности предполагает органическую связь между ранее усвоенным материалом и вновь усваеваемым. При обучении актуализированной паронимической лексике этот принцип особенно важен, потому что постоянно привлекается паронимическая лексика, изученная на предыдущем этапе. Это необходимо для дифференциации значений паронимических лексем, предупреждения ошибок в их употребллении.

Соблюдение приниипа науиности проявляется в системе подачи материала, презентации актуализированных паронимов-прилагательных в сербской аудитории. Эта система соответствует требованиям современного уровня методической науки. Актуализированная паронимическая лексика относится к числу труднодоступных, это обусловлено рядом лингвистических и психологических факторов. Доступность понимания данных лексем достигается в основном через систему упражнений при введении и закреплении паронимов.

Соблюдение приниипа прочности достигается за счёт систематического контроля со стороны преподавателя, проведения контрольных срезов после завершения работы над темой, многократной повторяе- 
мости актуализированных паронимов в тексте и активизации их в речевых упражнениях.

Прини,ип индивияуализаиии и учета спеиифики ауgитории предполагает учет не только сугубо индивидуальных, но и групповых особенностей сербских учащихся, в частности, потребностей, интересов, уровня подготовленности к восприятию данного материала того или иного контингента учащихся. Специфика актуализированной паронимической лексики обуславливает использование главным образом средств внутренней языковой наглядности.

Внутренняя языковая наглядность реализуется за счёт выполнения упражнений с использованием различного рода группировок актуализированных паронимов-прилагательных по словообразовательному, семантическому и другим принципам.

В соответствии с приниипом коммуникативности предполагается использование изучаемого явления в естественных условиях речевого общения.

Система упражнений и заданий, представленная в данной статье, поможет повысить мотивацию сербов в изучении русского языка через их знакомство с актуальными изменениями, протекающими в современном русском языке на синхронном уровне, обогатить активный и пассивный лексический запас сербских учащихся актуализированной лексикой, что позволит им свободно ориентироваться в языке мультимедийных российских СМИ, и будет способствовать формированию их языковой и культурологической компетенций.

За исходный уровень обученности учащихся принимается второй уровень системы российского государственного сертификационного тестирования по русскому языку как иностранному. За конечный уровень обучения принимался четвертый сертификационный уровень по русскому языку как иностранному.

Основой предлагаемой системы упражнений и заданий стала текстотека, сформированная для работы над актуализированными паронимами-прилагательными, включающая учебно-аутентичные тексты (преимущественно тексты из СМИ и Интернета), содержащие данные единицы.

Текстовый материал в основном ориентирован на задачи восприятия материалов современных российских СМИ (устных и письменных). Использовались также тексты-интервью с деятелями культуры и искусства, участниками делового общения. Материал сгруппирован в рамках следующих разговорных тем: «Современное искусство»; «Экономика»; «Проблемы современного общества».

Отобранный лексический материал распределен в соответствии со следующими задачами общения: 
1) оценка ситуации, проблемы (глобальный (глобалан) - глобалистский; гуманистический - гуманный (хуман); ияеологический (ияеолошки) - ияеологизированный; репрессивнысй (репресиван) - репрессированный; экологический (еколошки) - экологичный и др.);

2) характеристика общественно-политической жизни в России и в Сербии (бюрократический (бирократски) - бюрократичный - бюрократизированный; gемократический (gемократски) - gемократичный - gемократизированный; политизированный - политический (политички) - политичный (тактичан); эмигрантский (емигрантски) - эмиграционный и др.);

3) характеристика финансово-экономической ситуации в России и в Сербии (аренgаторскиц - ареняный (ареняни); декларативный (gекларативан) - gекларационный; gепозитарный - gепозитный; gефицитарный - gефицитный; конвертаиионный конвертируемый; маркетинговый-маркетологический и др.).

Все задания и упражнения разделены на языковые, условно-речевые и речевые.

Работа над актуализированными паронимами-прилагательными в большей степени зависит от того, к каким тематическим группам они относятся. Выделяются следующие основные этапы этой работы: npegъявление, семантизация, закрепление и активизация минимизированного массива лексики.

Усвоение актуализированной паронимической лексики в основном происходит в процессе работы над текстом и при порождении речи, что требует не только выделения из паронимической парооппозиции / паронимического ряда нужного паронима, но и анализа и прогнозирования трудностей, связанных с восприятием актуализированных паронимов-прилагательных, содержащихся в учебных материалах.

Следует обращать внимание на то, что при работе над актуализированными паронимами-прилагательными в сербской аудитории необходимо учитывать их собственно словарное значение, форму, функционирование в составе высказывания (парадигматическую значимость, особенности сочетаемости и др.).

В предлагаемом комплексе упражнений дается поэтапная организация процесса обучения актуализированной паронимической лексике, включающая три этапа: подготовительный (предтекстовый), притекстовый и послетекстовый.

Предтекстовые упражнения представлены двумя видами:

- упражнения, направленные на формирование навыков узнавания актуализированной паронимической лексики;

- упражнения на снятие языковых трудностей. 
Притекстовые упражнения призваны обеспечить целенаправленный поиск заданной информации в процессе чтения текста.

Послетекстовые упражнения направлены на формирование устойчивости и стабильности навыка на основе автоматизации операций установления лексических связей актуализированных паронимов-прилагательных.

Рассмотрим комплекс упражнений и заданий с точки зрения соответствия видов и типов упражнений этапам формирования лексического навыка.

На первом ознакомительн-подготовительном этапе происходит первичное предъявление и семантизация новых актуализированных паронимов.

Целью этого этапа является формирование языковых лексических навыков, осознание действий с лексическим материалом, знакомство со слуховым и речемоторным образом актуализированных паронимов, установление синтагматических, деривационных, парадигматических связей, осмысление специфики значений актуализированных паронимов, дифференциация значений данных слов. Это языковые и частично, условно-речевые упражнения, которые носят предтекстовый характер.

Упражнения первого этапа представлены следующими видами:

- упражнения на дифференциацию значения актуализированных паронимов;

- упражнения на сочетаемость актуализированных паронимов;

- упражнения на наблюдение и использование актуализированных паронимов в контексте;

- условно-речевые упражнения на подстановку и трансформацию.

Приведем примеры.

Пример 1. Обратите внимание, с какими существительными соотносятся слеgующие прилагательные: абсурдистский - абсурдизм; абсурдный (апсурgан) - абсурд.

Пример 2. Прочитайте опреgеления актуализированных паронимов, укажите разницу в их значении. Обратите внимание на то, ито прилагательные абсурgистиский и абсурgный перевоgятся на сербский язык через

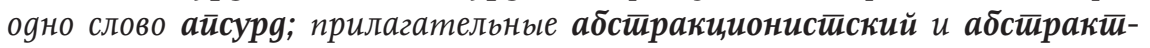
ньй перево gятся через о оно слово айсииракиионизам.

- абсурдистский - относящийся к абсурguзму, т.е. направлению драматургии, представляющему мир как нелепость, например, абсурдистская пьеса.

- абсурдный - (ancypgaн) относящийся к абсурgy, т.е. не имеющий смысла, нелепый, например, абсурдное высказывание, абсурдное поведение. 
- абстракционистский - относящийся к абстиракционизму, т.е. направлению в изобразительном искусстве XX века, представители которого (аббтракционисты) отказываются от изображения реальных предметов и явлений и представляют их в виде сочетаний геометрических форм, цветовых пятен и линий, например, абстракционистская живопись, абстракционистское направление, течение в искусстве.

- абстрактный - (апстрактан) основанный на абстиракиии, т.е. отвлеченный, неконкретный, например, абстрактное мышление, абстрактная идея.

Пример 3. Прочитайте предложения. Обратите внимание, ито прилагательное абстракционистский относится к существительному «абсииракиионизм», а прилагательное абсииракииный относится к существительному «абстираки,я». Укажите, какие из выделенных актуализированных паронимов-прилагательных имеют слеgующие значения «основанный на абстракиии, отвлеченный, неконкретный», а какое обозначает «относящийся к абстракиионизму, к абстракиионистам».

1. Многие жалуются, что современные картины уж слишком абстрактны, что они имеет мало общего с реальностью, и что трудно догадаться, что именно хотел показать автор в той или иной своей работе. 2. Хиллари Клинтон в свое время повесила в Белом доме абстракционистские полотна Василия Кандинского. 3. Людям с сердечно-сосудистой аритмией грозит снижение умственных способностей. У сердечников несколько подавлены абстрактное мышление, память, внимание, способности к анализу. 4. Абстрактная композиция К.Цибер, на которой причудливо переплетаются древние символы, лица людей, маски, изображения животных, обратила на себя внимание зрителей. 5. Мэтр самарской живописи С.Федоров представлен на выставке абстракционистским полотном «Космическая музыка». 6. Валентин Булгаков - молодой, доверчивый секретарь Толстого, увлечен абстрактными толстовскими идеями об идеальной любви, но, наблюдая семейные отношения самого писателя, понимает, что в реальной жизни все гораздо сложнее, чем в теории.

Пример 4. Вставьте вместо точек нужные по смыслу слова:

... пьеса связана с абсурдизмом как жанром драматургии (абсурgистскиц - абсуруныц̆).

... часть войск или флота следует на марше впереди главных сил (авангаряистский-авангарgный).

... называется живопись, представители которой отказываются от изображения реальных предметов и явлений и представляют их в виде соче- 
таний геометрических форм, цветовых пятен и линий (абстракиионистскиц̆-абстрактныц).

Основной задачей второго - стандартизирующе-ситуативного этапа является автоматизация и дифференциация речевых навыков с целью достижения максимально высокого уровня правильного словоупотребления актуализированных паронимов-прилагательных. Речевые лексические навыки становятся автоматизированными благодаря выполнению условно-речевых упражнений, обеспечивающих частотность употребления лексических единиц в речи. Упражнения носят притекстовый и послетекстовый характер.

На этом этапе предлагаются следующие виды упражнений:

- упражнения на наблюдение за функционированием актуализированных паронимов в тексте;

- упражнения на сочетаемость актуализированных паронимов;

- упражнения на составление и завершение предложений с употреблением новых актуализированных паронимов;

- вопросно-ответные упражнения в связи с содержанием прочитанного текста;

- упражнения на составление монолога-воспроизведения с опорой на новые слова и словосочетания.

Приведем примеры.

Пример 1. Прочитайте фрагмент интервью с наровным артистом РФ, веgущим актером Театра на Таганке Валерием Золотухиным. Обратите внимание на употребление паронимов в тексте.

Московский театр «Модернъ» представил абсурgистскую комеgию знаменитого польского драматурга Славомира Мрожека «Счастливое событие» с Валерием Золотухиным в главной роли.

«Я согласился на предложение сыграть эту роль прежде всего потому, что ничего подобного я в театре не играл. Для меня это что-то новое: новая драматургия абсурдиста Мрожека, с которой я впервые встретился в работе, новый режиссер, актеры, новая атмосфера», - сообщил Валерий Золотухин.

Золотухин добавил, что ему было интересно попробовать свои силы в новой обстановке - по его выражению, «это как вступить в соревнование с самим собой». «Мне интересно было работать со Светланой Враговой - замечательным организатором и талантливым режиссером, я влюбился в этот театр и его актеров. Для меня был очень полезным этот период», - добавил он. 
По сюжету пьесы, в обычном доме с красивым видом на Монблан разворачивается необычная абсуряная история: домашний тиран Старик не разрешает собственному сыну с женой завести детей, поскольку, по его мнению, ребенок может нарушить пирамиду власти в семье, складывавшуюся годами. Абсурд в режиссерском решении Светланы Враговой вырастает до масштабов притчи.

Пример 2. Дополните фразы по ахояящими по смыслу актуализированными паронимами абсурgисйский или абсурgный.

... комедия знаменитого польского драматурга Славомира Мрожека «Счастливое событие» с Валерием Золотухиным в главной роли была представлена Московским театром «Модернъ».

Домашний тиран Старик не разрешает собственному сыну с женой завести детей, поскольку, по его мнению, ребенок может нарушить пирамиду власти в семье, складывавшуюся годами - вот такая ... история разворачивается по сюжету пьесы, в обычном доме с красивым видом на Монблан.

Пример 3. Составьте предложения со словосочетаниями:

абсуруисиская комеgия

абсуруная истиория

На третьем - варьирующе-ситуативном этапе происходит дальнейшая автоматизация речевых лексических навыков. Упражнения должны быть ситуативно обусловленными. Кроме того, упражнения должны быть в значительной степени стереотипными, т.е. содержащими знакомые студентам актуализированные паронимы в знакомых словосочетаниях, так как необходимо использовать все возможные виды «опор», формирующих навыки говорения.

На данном этапе предлагаются следующие виды упражнений:

- упражнения на формирование устного монологического высказывания с опорой на план;

- упражнения, направленные на интерпретацию высказываний других учащихся;

- упражнения на дополнение информации текста своей информацией.

Пример 1.

а) Составьте план к фрагменту интервью с народным артистом РФ, веgущим актером Театра на Таганке Валерием Золотухиным.

б) Составьте монолог-воспроизвеgение фрагмента интервью с опорой на план, используйте актуализированные паронимы-прилагательные абсуряисииский и абсурgный. 
1. Вы корреспондент модного журнала и хотите взять интервью у известного актера Валерия Золотухина. Позвоните Валерию 3олотухину и расспросите его, почему он согласился сыграть роль тирана-Старика, в ием особенность этой пьесы.

2. Рассканите вашей поgруге, gавней поклоннище твориества известного актера Валерия Золотухина о его новой роли в спектакле «Сиастливое собьтие», используйте актуализированные паронимы абсурgистиский и абсурgный.

Пример 2. Работаем в парах!

1. Вы gавний поклонник актера. Вы участвовали в конкурсе на луишее письмо артисту и побеgили, ваш приз - бесплатный билет на спектакль "Счастливое собьттие» и встреча с Валерием 3олотухиным. Заяайте вопросы любимому актеру; ответьте на вопросы поклонника; в ходе бесеgы используйте паронимы абсурgисииский и абсурgный.

2. Примите участие в обсужяении проблемы "Современное искусство - абсуряно». Выражая свою позииию, используйте актуализированные паронимы абсурgисйский и абсурдный.

Необходимо отметить, что представленная система упражнений и заданий может рассматриваться как модель, обладающая определенными универсальными характеристиками, которая может быть перенесена на иной лексический материал. Являясь рабочим представлением, образом серии создаваемых на ее основе вариативных систем упражнений и заданий по обучению сербских учащихся лексике (в нашем случае - паронимической), предлагаемая модель носит нормативный характер, в определенном смысле играет роль стандарта и образца, отвечая требованиям, обеспечивающим ее функционирование.

\section{Цитирана литература}

Митрофанова, О.Д., Костомаров, В.Г. Методика преподавания русского языка как иностранного. Москва: Русский язык, 1990.

Щукин, А.Н. Методика преподавания русского языка как иностранного: Учебное пособие. Москва: Высшая школа, 2003. 
Марија Михајловна Вереитинова

\section{МЕТОДИЧКИ МОДЕЛ ПРЕЗЕНТАЦИЈЕ АКТУАЛИЗОВАНЕ ПАРОНИМСКЕ ЛЕКСИКЕ У СРПСКОЈ СРЕДИНИ}

\section{Резиме}

У раду се разматра етапна организација процеса усвајања актуализиране паронимске лексике (припремна (предтекстуална), притекстуална и послетекстуална етапа) у српској средини. Наводе се примери из комплекса вежбања и задатака.

Кључне речи: актуализирани пароними-придеви, паронимске опозиције, паронимски низови, општедидактички принципи, лингводидактички принципи, комплекс вежбања 